УДК 633.112.1«321»:631.527:631.559 (470.44)

СЕЛЕКЦИОННАЯ ОЦЕНКА СОРТООБРАЗЦОВ

И ЛИНИЙ ЯРОВОЙ ТВЁРДОЙ ПШЕНИЦЫ

В ЗАСУШЛИВЫХ УСЛОВИЯХ НИЖНЕГО ПОВОЛЖЬЯ

Шьюрова Н.А., Субботин А.Г., Жужукин В.И., Нарушев В.Б., Мухатова Ж.Н., Башинская О.С.

Саратовский ГАУ им. Н.И. Вавилова, Саратов, е-mail: subbotinag2014@mail.ru

Проведенные исследования по изучению сортов и новых линий яровой твёрдой пшеницы позволили выявить наиболее перспективные сортообразцы для дальнейшей селекции. По устойчивости к пыльной головне выделялись сорта Аннушка, Безенчукская 182 и линии СП-8/2019, ЛСГАУ-9; по устойчивости к засухе - сорта Елизаветинская, Луч 25, Краснокутка 13 и линии ЛСГАУ-7, ЛСГАУ-9 и СП-8/2019; по содержанию белка в зерне - сорта Луч 25, Саратовская золотистая, Безенчукская 182, Краснокутка 13 и линии ЛСГАУ-9, ЛСГАУ-11 и СП-8/2019; по урожайности зерна - сорт Луч 25 и линии ЛСГАУ-7, СП-8/2019. Проведенные исследования по изучению новых селекционных линий яровой твёрдой пшеницы селекции СГАУ, относящихся к различным группам спелости, выявили перспективные образцы для дальнейшей селекции. Исследования селекционеров Саратовского ГАУ позволили выявить превосходство группы позднеспелых линий, имеющих наивысшие показатели: по массе зерна с главного колоса выделились линии ЛС-165 и ЛС-179 - 1,71 и 1,89 г соответственно, по количеству зёрен с главного колоса - линии ЛС-179 и ЛС-165 - 50,6 и 52,9 шт соответственно, по наибольшей величине флагового листа - линии ЛС-151 и ЛС-179 - 39,2 и 39,1 см² соответственно. В результате исследований выделена для передачи на государственное сортоиспытание селекционная линия СП-8/2019 (Экспрессия), превосходящая по урожайности, а также по показателям элементов структуры урожая и качества зерна сорт-стандарт и все другие сорта яровой твердой пшеницы в условиях Нижнего Поволжья.

Ключевые слова: яровая твёрдая пшеница, сорт, линия, урожайность, качество, продуктивность, Нижнее Поволжье

\title{
SELECTIVE EVALUATION OF GRADE SAMPLES AND LINES OF SPRING HARD WHEAT IN DRY CONDITIONS OF LOWER VOLGA REGION
}

\author{
Shyurova N.A., Subbotin A.G., Zhuzhukin V.I., Narushev V.B., \\ Mukhatov Zh.N., Bashinskaya O.S.
}

Saratov State University named after N.I. Vavilov, Saratov, e-mail: subbotinag2014@mail.ru

\begin{abstract}
The article presents the results of studies on the assessing different varieties and new selection lines of spring hard wheat in the conditions of the Lower-Volga region. Research, carried out to study varieties and new lines of spring hard wheat have revealed the most promising variety samples for further selection. According to resistance against dust head, variety Annushka, Besenchuk 182, SP-8/2019 and LSGAU-9 were allocated. According to drought resistance - Elizabeth variety, Beam 25 grade, Krasnokutka 13 grade, LSGAU lines - 7, LSGAU - 9 and SP-8/2019; In terms of protein content in grain - class Beam 25, class Saratov golden, class Besenchuk 182, class Krasnokutka 13, lines LSGAU -9, LSGAU-11 and SP - 8/2019; Grain yield - Beam 25 grade, LSGAU lines 7 and CП-8/2019. A research was carried out to study new selection lines of spring hard wheat of SGAU selection belonging to different ripeness groups revealed promising samples for further selection. Studies of breeders of Saratov GAU allowed to reveal superiority of the group of late-life lines, which have the highest indicators: on the mass of grain from the main ear LS-165 and LS-179 lines - 1.71 and $1.89 \mathrm{~g}$ according to, by amount of grains from the main ear - LS-179 and LS-165 line - 50.6 and 52.9 pieces respectively, in the largest size of a flag leaf - LS151 and LS-179 line -39.2 and $39.1 \mathrm{~cm} 2$ respectively were allocated. As a result of the studies, selection line of SP-8/2019 (Expression), superior in yield, as well as in all indicators of crop structure and grain quality of gradestandard and other varieties of spring hard wheat, has been identified for transmission to the State.
\end{abstract}

Keywords: spring hard wheat, variety, line, yield, quality, pro-ductility, Lower Volga region

Наблюдаемое в последние годы потепление климата оказывает существенное влияние на развитие сельского хозяйства в мире и в Российской Федерации. Усиливающаяся в результате хозяйственной деятельности разбалансировка природных процессов приводит к существенной вариации в режимах выпадения осадков, температуре и к увеличению частоты природных аномалий - засух, заморозков, ура- ганов и наводнений. Данные Министерства природы РФ показывают, что только за двадцатилетний период исследований, с 1990 по 2010 г., количество природных катастроф возросло в 4 раза и отмечается тенденция их дальнейшего увеличения [1]. Анализ погодных данных за этот же период в Нижневолжском регионе показывает, что среднегодовая температура воздуха повысилась на $0,5-0,7^{\circ} \mathrm{C}$ и отмечается заметный 
рост дефицита осадков в летний период. Учитывая нестабильность климатических условий в регионе имеется острая необходимость в создании новых сортов полевых культур, устойчивых к комплексу абиотических факторов [2, 3].

Проблема стабилизации производства зерна твёрдой пшеницы в России является актуальной и решается селекционными методами создания новых высокоурожайных, засухоустойчивых и холодостойких сортов с хорошо развитой корневой системой, устойчивых к комплексу биотических и абиотических стрессовых факторов [4-6], а также путем внедрения современных биоэнергетически эффективных элементов технологии возделывания [7-9].

Цель исследования: провести оценку коллекции сортов и новых перспективных линий яровой твёрдой пшеницы по основным хозяйственно ценным признакам в условиях засушливого Нижнего Поволжья.

\section{Материалы и методы исследования}

Исследования осуществлялись на опытных полях ФГБОУ ВО «Саратовский ГАУ», расположенных в УНПК «Агроцентр» (Caратовское Правобережье) и УНПО «Поволжье» Энгельсского района (Саратовское Левобережье) Саратовской области.

Климат региона - континентальный, засушливый. Годовая сумма осадков - 350450 мм. Среднегодовая температура составляет $\pm 5,5-6,5^{\circ} \mathrm{C}$. На территории региона преобладают чернозёмные и каштановые почвы с содержанием гумуса около 3,5$5,0 \%$. Содержание нитратного азота - низкое, доступного фосфора - низкое и среднее, обменного калия - высокое.

В 2016-2019 гг. были заложены и проведены следующие полевые эксперименты:

1. Конкурсное изучение коллекции сортов и линий яровой твёрдой пшеницы.

2. Сравнительная оценка продуктивности селекционных линий яровой твёрдой пшеницы.

3. Морфофизиологическая оценка селекционных линий Саратовского ГАУ.

Погодные условия в годы проведения полевых опытов соответствовали засушливым условиям Нижнего Поволжья.

Опытные делянки размещали по предшественнику озимая пшеница. Соблюдалась рекомендуемая зональная технология возделывания яровой твердой пшеницы. В питомнике конкурсного испытания посев проводился в третьей декаде апреля сеялкой ССНП-16 рядовым способом с между- рядьями 15 см, нормой высева 4,0 млн всхожих семян на 1 га. Площадь делянки - $20 \mathrm{M}^{2}$. Повторность - трехкратная, размещение вариантов рендомизированное. В коллекционном и селекционных питомниках (СП-2) сортообразцы размещали на делянках площадью 0,72 м² (длина рядка 1,2 м, число рядков - 3, междурядье - 0,2 м). На делянке высевали 300 зерен. Повторность трехкратная. Посев осуществляли аппаратами для ручного высева.

Наблюдения и учёты проводились по методике Государственного сортоиспытания [10]. Уборка урожая проводилась комбайном «TERRION-2010» в первой декаде августа. Качественные показатели зерна определяли по общепринятой методике в учебно-научно-производственном комплексе «Селекция и экспериментальное семеноводство» ФГБОУ ВО «Саратовский ГАУ им. Н.И. Вавилова».

\section{Результаты исследования и их обсуждение}

Проведенная оценка коллекции по хозяйственно ценным признакам позволила выявить особенности реакции изучаемых сортов и линий на погодные факторы.

Результаты показывают, что высокая температура воздуха и дефицит осадков приводят к сокращению вегетационного периода и в связи с этим важную роль у современных сортов играет такой показатель, как продолжительность периода «всходы - колошение». Период «всходы колошение» у сорта-стандарта Николаша и сорта Безенчукская 209 составил 43,0 суток (табл. 1).

Среди изучаемых сортов и линий выделены образцы с укороченным периодом 42,3-42,8 суток - сорта Краснокутка 13 и Саратовская золотистая.

Наиболее продолжительный период «всходы - колошение» отмечен у сортов Крассар и Безенчукская 200 - 45,7 и 46,7 суток соответственно. У созданных учеными СГАУ селекционных линий яровой твёрдой пшеницы отмечалась различная продолжительность периода «всходы - колошение». Так, линия ЛСГАУ-7 незначительно отличалась от сорта-стандарта Николаша - у нее продолжительность периода «всходы - колошение» составила 43,1 суток. Новые линии ЛСГАУ-9 и СП 8/2019 превышали сорт-стандарт на $1,2(44,2)$ и $1,6(44,6)$ суток соответственно, а у линии ЛСГАУ-11 данный показатель составил 45,3 суток, на 2,3 суток превышая стандарт. 
党

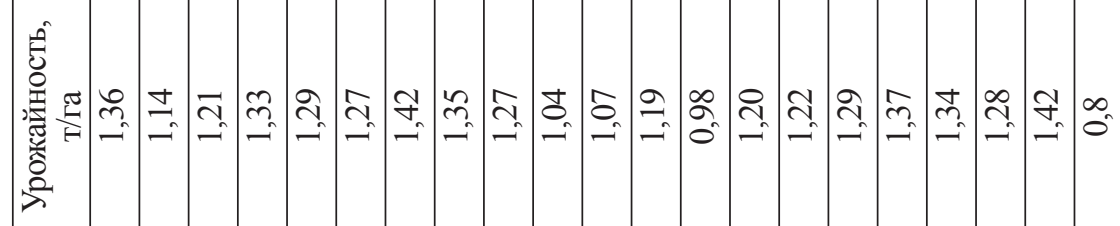



$\circ$

亩

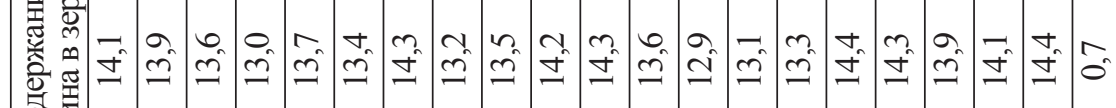
ن

命

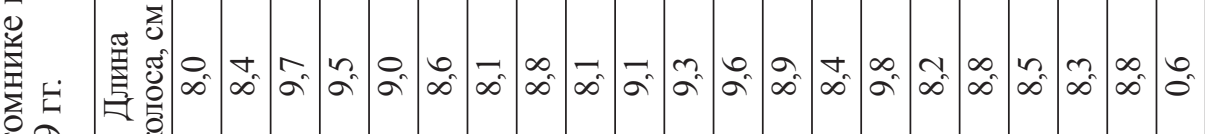

응

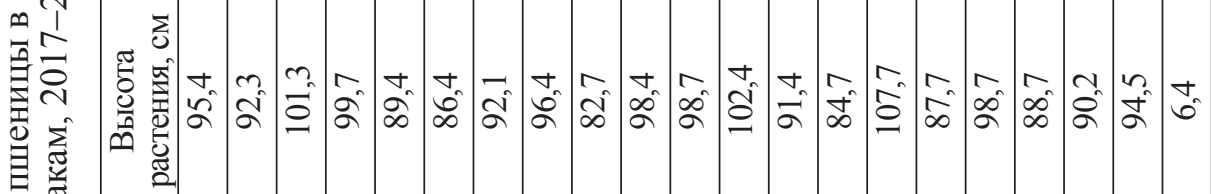

'哭

: $\hat{\theta}$ 兽

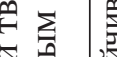

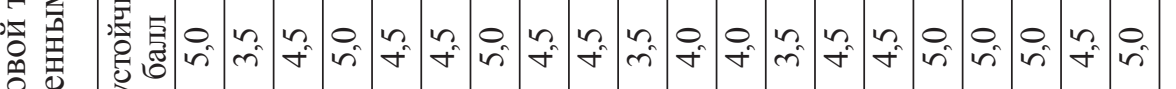

क्षे

要 (2) 峁

政

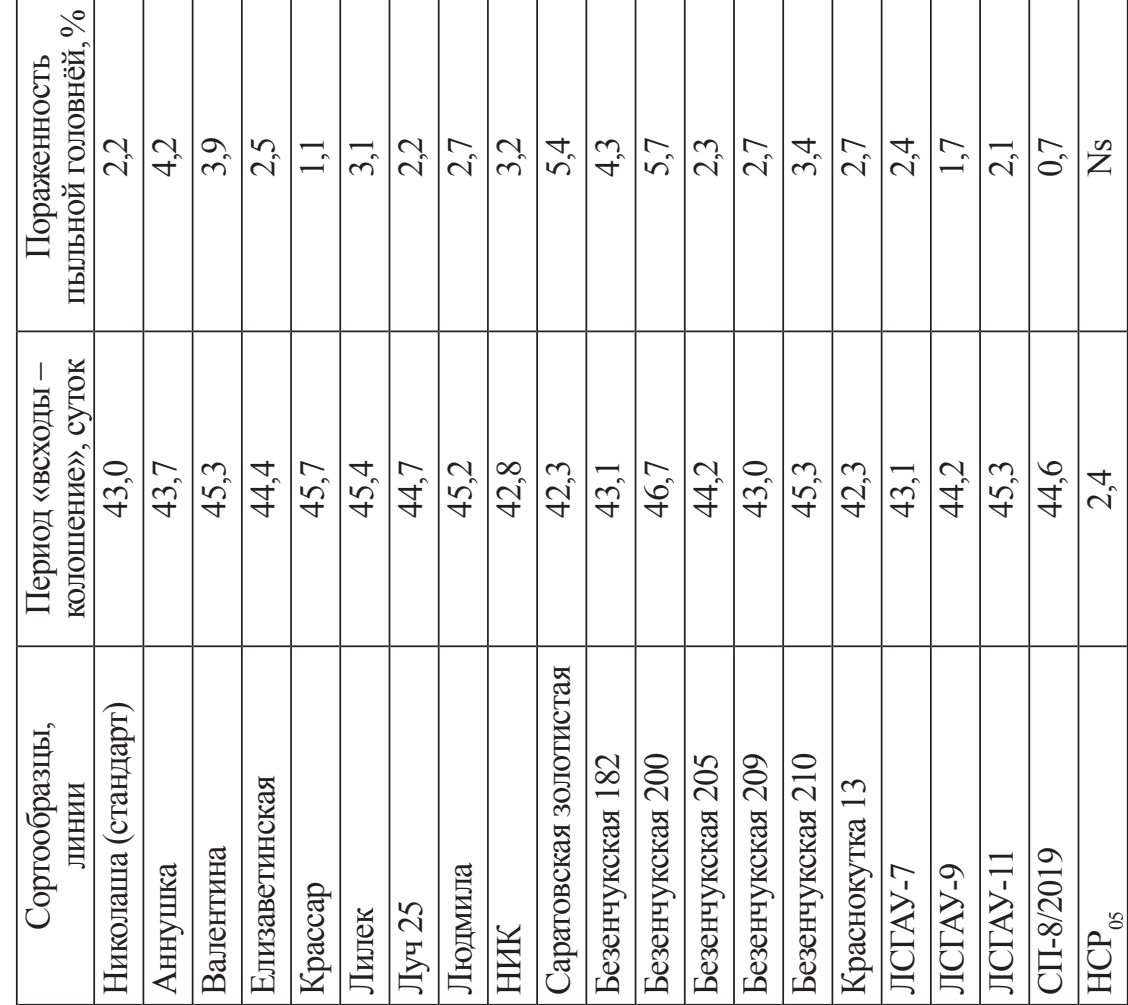


В условиях Нижнего Поволжья существенное значение в формировании урожая яровой твердой пшеницы имеет устойчивость растений к пыльной головне, что, естественно, обязательно учитывается при создании новых сортов и перспективных линий. Оценка коллекции сортообразцов яровой твёрдой пшеницы показала различную устойчивость к данному заболеванию. Так, у сорта-контроля Николаша доля пораженных пыльной головней растений составила $2,2 \%$. У сортов Луч 25 и Безенчукская 205, линий ЛСГАУ-7 и ЛСГАУ-11 доля пораженных пыльной головнёй растений приближалась к стандарту $-2,1-2,4 \%$. Несколько выше отмечали поражение пыльной головней на опытных делянках с сортами Аннушка, Лилёк, НИК, Саратовская золотистая, Безенчукская 200, Безенчукская 210, Безенчукская 182, Валентина доля пораженных растений варьировала от 3,1 до 5,7\%. При этом наибольшее количество растений пораженных пыльной головней отмечено у сортов Саратовская золотистая - 5,4\%, Безенчукская $200-$ $5,7 \%$. У селекционных линий наименьшая величина пораженных пыльной головней растений отмечена у линий СП-8/2019 $(0,7 \%)$, ЛСГАУ $-9-(1,7 \%)$.

Условия Нижнего Поволжья характеризуются повышенной температурой и дефицитом осадков, что вызывает острую необходимость в создании новых засухоустойчивых сортов полевых культур. В наших исследованиях растения твёрдой пшеницы оценивали по устойчивости к засушливым условиям. Оценка сортообразцов по устойчивости к засухе показала, что сортообразцы Аннушка, Саратовская золотистая, Безенчукская 205 обладают устойчивостью в 3,5 балла, тогда как у большинства сортообразцов данный показатель варьировал от 4,0 до 4,5 балла. Наибольший показатель засухоустойчивости отмечен у сорта-стандарта Николаша (5,0 баллов). Кроме того, высокой устойчивостью обладают сорта Елизаветинская, Луч 25 и Краснокутка 13, а также линии ЛСГАУ-7, ЛСГАУ-9 и СП-8/2019.

Показатель высоты растений варьировал от 82,7 до 107,7 см. Наименьшая высота отмечена у сортов НИК $(82,7$ см), Безенчукская 209 (84,7 см), Лилёк $(86,4$ см) и Краснокутка 13 (87, 7 см). Максимальная высота отмечена у сортов Валентина (101,3 см), Безенчукская $200(102,4$ см) и Безенчукская 210 (107,7 см). У селекционных линий высота растений составила: ЛСГАУ-9 - 88,7 см,
ЛСГАУ-11 - 90,2 см, СП-8/2019 - 94,5 см и ЛСГАУ -7 - 98,7 см.

Величина колоса у изучаемых сортообразцов в проведенных полевых исследованиях варьировала от 8,0 до 9,8 см. При этом наименьшая длина колоса была у сорта-стандарта Николаша $-8,0$ cм, а большая - у сортов Безенчукская $210(9,8 \mathrm{~cm}), \mathrm{Ba}-$ лентина (9,7 см), Безенчукская 200 (9,6 см), Елизаветинская (9,5 см). У созданных селекционных линий СГАУ длина колоса была практически равной $-8,3-8,8$ см.

Современные сорта яровой твердой пшеницы в условиях Нижнего Поволжья должны обладать высокой засухоустойчивостью и на фоне этого формировать высокие и стабильные урожаи высококачественного зерна.

Одной из важнейших характеристик яровой твёрдой пшеницы является признак - «содержание протеина в зерне». Оценка сортообразцов по данному показателю позволила выявить следующие особенности. У сорта-стандарта Николаша содержание протеина в зерне составило $14,1 \%$. Превышение по данному показателю отмечено у сортообразцов Луч $25-14,3 \%$, Саратовская золотистая - $14,2 \%$, Безенчукская 182 - 14,3\% и Краснокутка 13 - 14,4\% и у линии ЛСГАУ-7 - 14,3\%, ЛСГАУ-11 $14,1 \%$, СП-8/2019 - 14,4\%.

Проведенная оценка сортообразцов по урожайности показала, что сорт Николаша в среднем за три года превышал большинство генотипов на 0,01-0,38 т/га по обсуждаемому показателю. Низкая урожайность отмечена у сортов Безенчукская 205 (0,98 т/га), сорта Саратовская золотистая (1,04 т/га), Безенчукская 182 (1,08 т/га). Превышение сорта-стандарта по урожайности выявлено у линии ЛСГАУ-7 (1,37 т/га), сорта Луч 25 и СП-8/2019 (1,42 т/га).

Комплексная оценка сортообразцов яровой твердой пшеницы во втором опыте позволила выявить ценную селекционную линию СГАУ - СП-8/2019. Сравнительная оценка с сортом-стандартом Саратовская золотистая показала, что в среднем за три года исследований урожайность линии СП8/2019 была выше на 0,15 т/га (табл. 2).

Натурная масса у нового сортообразца СП-8/2019 (Экспрессия) варьировала по годам от 748 до 784 г/л, а в среднем за три года исследований составила 762 г/л, что превышало сорт-стандарт на 14 г/л. Масса 1000 зерен у нового сортообразца достигала величины 41,9 г, у сорта-стандарта Саратовская золотистая она составила 40,9 г. 
Кроме того, отмечено превышение нового сортообразца СП-8/2019 (Экспрессия) над сортом-стандартом по стекловидности, содержанию сырой клейковины и сырого протеина в зерне.

Изучение в третьем опыте коллекции линий яровой твёрдой пшеницы селекции
Саратовского ГАУ по основным хозяйственно ценным признакам показало, что в группе ультраскороспелых линий масса зерна с главного колоса варьировала от 0,87 г (ЛСГ-64) до 1,62 г (ЛСГ-75), при коэффициенте вариации на данных вариантах $34,5 \%$ и $17,4 \%$ соответственно (табл. 3 ).

Хозяйственные и биологические свойства изучаемых сортообразцов

Таблица 2 яровой твердой пшеницы

\begin{tabular}{|l|c|c|c|c|c|c|c|c|}
\hline \multirow{2}{*}{ Показатели } & \multicolumn{3}{c|}{$\begin{array}{c}\text { Линия СП-8/2019 } \\
\text { (Экспрессия) }\end{array}$} & \multicolumn{3}{c|}{ Сорт-стандарт } \\
& \multicolumn{3}{|c|}{ Саратовская золотистая } \\
\cline { 2 - 10 } & 2016 г. & 2017 г. & 2018 г. & среднее & 2016 г. & 2017 г. & 2018 г. & среднее \\
\hline 1. Урожайность зерна, т/га & 1,87 & 2,23 & 1,46 & 1,85 & 2,01 & 1,81 & 1,29 & 1,70 \\
\hline НСР $_{05}, \mathrm{~T} /$ га & 0,05 & 0,13 & 0,03 & 0,06 & 0,05 & 0,13 & 0,03 & 0,06 \\
\hline 2. Натура зерна, г/л & 748 & 754 & 784 & 762 & 743 & 742 & 759 & 748 \\
\hline 3. Масса 1000 зерен, г & 42,5 & 42,9 & 40,4 & 41,9 & 42,3 & 40,8 & 39,7 & 40,9 \\
\hline 4. Стекловидность, \% & 85 & 88 & 84 & 86 & 83 & 82 & 81 & 82 \\
\hline 5. Содержание сырой клейковины, \% & 29,4 & 28,1 & 29,7 & 29,1 & 28,6 & 28,8 & 29,4 & 28,9 \\
\hline 6. Содержание сырого протеина, \% & 12,0 & 11,5 & 12,6 & 12,0 & 11,7 & 11,8 & 12,4 & 12 \\
\hline
\end{tabular}

Изменчивость морфофизиологических признаков наиболее урожайных линий яровой твердой пшеницы селекции Саратовского ГАУ (среднее за 2018-2019 гг.)

\begin{tabular}{|c|c|c|c|c|c|c|}
\hline \multirow{2}{*}{$\begin{array}{c}\text { № } \\
\Pi / \Pi\end{array}$} & \multicolumn{2}{|c|}{ Масса зерна главного колоса, г } & \multicolumn{2}{|c|}{ Число зерен главного колоса, шт. } & \multicolumn{2}{|c|}{ Площадь флагового листа, см² } \\
\hline & $\begin{array}{c}\text { среднее } \\
\text { значение }\end{array}$ & $\begin{array}{c}\text { коэффициент } \\
\text { вариации, \% }\end{array}$ & $\begin{array}{c}\text { среднее } \\
\text { значение }\end{array}$ & $\begin{array}{c}\text { коэффициент } \\
\text { вариации, \% }\end{array}$ & $\begin{array}{l}\text { среднее } \\
\text { значение }\end{array}$ & $\begin{array}{c}\text { коэффициент } \\
\text { вариации, \% }\end{array}$ \\
\hline \multicolumn{7}{|c|}{ Ультраскороспелые } \\
\hline ЛСГ-57 & $1,11 \pm 0,03$ & $26,8 \pm 3,5$ & $39,7 \pm 1,1$ & $20,1 \pm 2,7$ & $21,8 \pm 0,7$ & $22,1 \pm 2,7$ \\
\hline ЛСГ-58 & $1,17 \pm 0,04$ & $23,4 \pm 3,2$ & $34,3 \pm 1,1$ & $21,4 \pm 2,8$ & $23,9 \pm 0,9$ & $26,0 \pm 3,1$ \\
\hline ЛСГ-64 & $0,87 \pm 0,03$ & $34,5 \pm 0,5$ & $22,5 \pm 0,7$ & $21,6 \pm 3,1$ & $16,3 \pm 0,5$ & $16,9 \pm 2,1$ \\
\hline ЛСГ-75 & $1,62 \pm 0,04$ & $17,4 \pm 2,4$ & $34,5 \pm 0,7$ & $16,7 \pm 2,3$ & $27,2 \pm 0,6$ & $18,9 \pm 2,5$ \\
\hline \multicolumn{7}{|c|}{ Раннеспелые } \\
\hline $\mathrm{C} \Pi-10$ & $1,09 \pm 0,04$ & $29,3 \pm 3,6$ & $30,2 \pm 1,0$ & $24,9 \pm 3,3$ & $22,7 \pm 0,6$ & $25,9 \pm 3,2$ \\
\hline СП-12 & $1,11 \pm 0,04$ & $25,4 \pm 3,2$ & $34,1 \pm 1,0$ & $21,8 \pm 2,7$ & $23,3 \pm 0,8$ & $23,4 \pm 3,2$ \\
\hline СП-18 & $1,07 \pm 0,04$ & $23,4 \pm 3,2$ & $30,5 \pm 0,8$ & $22,1 \pm 2,4$ & $18,7 \pm 0,7$ & $17,9 \pm 2,4$ \\
\hline СП-19 & $1,14 \pm 0,04$ & $23,2 \pm 3,1$ & $28,1 \pm 0,8$ & $17,8 \pm 2,1$ & $27,2 \pm 1,1$ & $23,2 \pm 3,1$ \\
\hline СП-20 & $1,09 \pm 0,04$ & $30,1 \pm 3,9$ & $35,2 \pm 1,3$ & $25,4 \pm 3,2$ & $21,2 \pm 0,5$ & $19,0 \pm 2,4$ \\
\hline СП-22 & $1,18 \pm 0,05$ & $28,7 \pm 3,7$ & $34,7 \pm 1,2$ & $23,0 \pm 2,4$ & $22,3 \pm 0,4$ & $20,6 \pm 2,7$ \\
\hline СП-23 & $1,29 \pm 0,05$ & $28,1 \pm 3,2$ & $45,6 \pm 1,8$ & $23,9 \pm 3,0$ & $26,7 \pm 0,7$ & $18,2 \pm 2,4$ \\
\hline СП-24 & $1,47 \pm 0,05$ & $23,2 \pm 3,5$ & $46,4 \pm 1,3$ & $20,1 \pm 2,8$ & $23,9 \pm 0,5$ & $16,7 \pm 2,6$ \\
\hline СП-25 & $1,14 \pm 0,04$ & $26,0 \pm 3,2$ & $43,2 \pm 1,2$ & $22,4 \pm 2,5$ & $24,2 \pm 0,7$ & $18,5 \pm 2,7$ \\
\hline СП-26 & $1,03 \pm 0,03$ & $19,5 \pm 2,4$ & $34,3 \pm 0,9$ & $16,8 \pm 2,2$ & $20,7 \pm 0,6$ & $21,2 \pm 2,4$ \\
\hline \multicolumn{7}{|c|}{ Среднераннеспелые } \\
\hline Л-35 & $0,92 \pm 0,04$ & $35,5 \pm 4,6$ & $37,6 \pm 1,4$ & $28,8 \pm 3,7$ & $28,6 \pm 0,4$ & $18,6 \pm 2,3$ \\
\hline Л-43/1 & $0,95 \pm 0,04$ & $29,5 \pm 3,8$ & $34,2 \pm 0,7$ & $16,7 \pm 2,5$ & $25,2 \pm 0,6$ & $17,0 \pm 2,1$ \\
\hline Л-52/2 & $1,42 \pm 0,06$ & $30,7 \pm 4,0$ & $36,9 \pm 1,1$ & $19,6 \pm 2,9$ & $30,1 \pm 0,7$ & $19,2 \pm 2,4$ \\
\hline Л-55/1 & $1,32 \pm 0,04$ & $21,6 \pm 2,8$ & $37,8 \pm 0,9$ & $17,2 \pm 2,9$ & $23,0 \pm 0,4$ & $20,8 \pm 2,2$ \\
\hline \multicolumn{7}{|c|}{ Среднеспелые } \\
\hline ЛС-18 & $1,71 \pm 0,07$ & $24,7 \pm 3,1$ & $45,5 \pm 1,6$ & $23,1 \pm 2,8$ & $25,9 \pm 0,3$ & $27,7 \pm 3,5$ \\
\hline ЛС-24 & $1,18 \pm 0,03$ & $19,2 \pm 2,3$ & $32,9 \pm 0,8$ & $18,2 \pm 2,0$ & $26,4 \pm 0,8$ & $20,3 \pm 2,6$ \\
\hline \multicolumn{7}{|c|}{ Позднеспелые } \\
\hline ЛC-151 & $1,16 \pm 0,04$ & $28,5 \pm 3,6$ & $38,2 \pm 1,1$ & $21,0 \pm 2,7$ & $39,2 \pm 0,8$ & $18,2 \pm 2,6$ \\
\hline ЛС-165 & $1,71 \pm 0,06$ & $26,8 \pm 3,6$ & $52,9 \pm 1,5$ & $19,1 \pm 2,2$ & $27,0 \pm 0,5$ & $19,9 \pm 2,1$ \\
\hline ЛС-169 & $1,42 \pm 0,04$ & $23,5 \pm 3,1$ & $40,2 \pm 1,0$ & $19,9 \pm 2,8$ & $26,7 \pm 0,7$ & $23,6 \pm 3,7$ \\
\hline ЛС-179 & $1,69 \pm 0,07$ & $31,2 \pm 4,3$ & $50,6 \pm 1,8$ & $24,8 \pm 3,5$ & $39,1 \pm 1,0$ & $20,4 \pm 2,4$ \\
\hline
\end{tabular}


Число зёрен в главном колосе изучаемых линий яровой твердой пшеницы варьировало от 22,5 (ЛСГ-64) до 39,7 шт. (ЛСГ-57).

Известно, что интенсивность налива зерна в колосе определяется площадью листьев верхнего яруса и длительностью его функционирования. В этой связи была проведена дифференциация изучаемых линий по площади флагового листа. Наименьшая величина площади отмечена у ЛСГ-64 - 16,3 см², а наибольшая - у линии ЛСГ-75 - 27,2 см$^{2}$.

В группе раннеспелых изучаемых линий яровой твёрдой пшеницы по массе зерна с главного колоса выделились образцы СП-23 и СП-24 - 1,29 и 1,47 г. соответственно. Наименьшая величина продуктивности колоса отмечена у линии СП-26 - 1,03 г. Подсчёт количества зёрен с одного колоса показал, что наименьшее число зерен сформировала линия СП-10 - 30,2 шт., а наибольшее - селекционная линия СП-24 - 46,4 шт. Наибольшую величину ассимиляционной поверхности флагового листа сформировали линии СП-23 - 26,7 см² и СП-19-27,2 см .

Определение морфометрических показателей растений в группе среднераннеспелых селекционных линий выявило наиболее перспективные образцы по данным признакам. Показатель массы зерна с главного соцветия варьировал от 0,92 (Л-35) до 1,43 г (Л-52/2), число зёрен изменялось в пределах от 34,2 (Л-43/1) до 37,8 шт. (Л-52/1), а площадь флагового листа от 23,0 (Л-55/1) до $30,1 \mathrm{cм}^{2}$ (Л-55/2).

У селекционных линий яровой твёрдой пшеницы, относящихся к группе среднеспелых, наибольшие параметры изучаемых признаков отмечены у образца ЛС-18: масса зерна главного колоса - 1,71 г, количество зерен в главном колосе - 45,5 шт., а площадь флагового листа достигала наибольшей величины у линии ЛС-24 - 26,4 см².

В группе позднеспелых линий в результате оценки были выявлены следующие лучшие образцы: по массе зерна с главного колоса выделились линии ЛС-165 и ЛС-179 - 1,71 и 1,89 г соответственно, по количеству зёрен с главного колоса - линии ЛС-179 и ЛС-165 - 50,6 и 52,9 шт. соответственно. Наиболышая величина флагового листа отмечена у линий ЛС-151 и ЛС-17939,2 и $39,1 \mathrm{~cm}^{2}$ соответственно.

\section{Заключение}

Проведенные исследования по изучению сортов и новых линий яровой твёрдой пшеницы позволили выявить наиболее перспективные сортообразцы для дальнейшей селекции.

По устойчивости к пыльной головне выделялись сорта Аннушка, Безенчукская 182 , линии СП-8/2019 и ЛСГАУ-9; по устойчивости к засухе - сорта Елизаветинская, Луч 25, Краснокутка 13, линии ЛСГАУ-7, ЛСГАУ-9 и СП-8/2019; по содержанию белка в зерне - сорта Луч 25, Саратовская золотистая, Безенчукская 182, Краснокутка 13, линии ЛСГАУ-9, ЛСГАУ-11 и СП-8/2019; по урожайности зерна - сорт Луч 25, линии ЛСГАУ-7 и СП-8/2019.

Проведенные исследования по изучению новых селекционных линий яровой твёрдой пшеницы селекции СГАУ, относящихся к различным группам спелости выявили перспективные образцы для дальнейшей селекции. В исследованиях выявлена тенденция превосходства группы позднеспелых линий: по массе зерна с главного колоса линии - ЛС-165 и ЛС179 - 1,71 и 1,89 г соответственно), по количеству зёрен с главного колоса - линии ЛС-179 и ЛС-165 - 50,6 и 52,9 шт. соответственно, по наибольшей величине флагового листа - линии ЛС-151 и ЛС-179 -

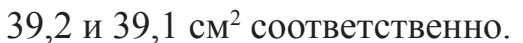

В результате исследований выделена для передачи на государственное сортоиспытание селекционная линия СП-8/2019 (Экспрессия), превосходящая по урожайности, a также по другим показателям элементов структуры урожая и качества зерна сортстандарт и все другие сорта яровой твердой пшеницы в условиях Нижнего Поволжья.

\section{Список литературы / References}

1. Гапонов С.Н., Шутарева Г.И., Попова В.М., Цетва Н.М., Паршикова Т.М. Результаты селекции яровой твёрдой пшеницы для засушливого Поволжья // Аграрный вестник Юго-Востока. 2017. № 1 (16). С. 16-17.

Gaponov S.N., Shutareva G.I., Popova V.M., Tsetva N.M., Parshikova T.M. Breeding results of spring durum wheat for the arid Volga region // Agrarnyy vestnik Yugo-Vostoka. 2017. № 1 (16). P. 16-17 (in Russian).

2. Бекетова Г.А., Бебякин В.М., Сайфуллин Р.Г. Чувствительность критериев в качестве зерна яровой мягкой пшеницы к неоднородности среды // Вестник Саратовского госагроуниверситета им. Н.И.Вавилова. 2011. № 5. С. 3-5.

Beketova G.A., Bebyakin V.M., Sayfullin R.G. Sensitivity of quality criteria of summer soft wheat grain to heterogeneity of environment // Vestnik Saratovskogo gosagrouniversiteta im. N.I. Vavilova. 2011. № 5. P. 3-5 (in Russian).

3. Васильчук Н.С., Шутарева Г.И., Гапонов С.Н., Попова В.М., Еременко Л.В., Паршикова Т.М., Горбань О.И. Саратовские сорта яровой твердой пшеницы для засушливых условий Поволжья // Сборник научных трудов (посвящается 135-летию со дня рождения Г.К. Мейстера и 100-летию со дня основания Аркадакской опытной станции. Саратов, 2009. C. 82-89.

Vasilchuk N.S., Shutareva G.I., Gaponov S.N., Popova V.M., Eremenko L.V., Parshikova T.M., Gorban O.I. Saratov 
varieties of spring durum wheat for the dry conditions of the Volga region // Sbornik nauchnykh trudov (posvyashchayetsya 135-letiyu so dnya rozhdeniya G.K. Meystera i 100-letiyu so dnya osnovaniya Arkadakskoy opytnoy stantsii. Saratov, 2009. P. 82-89 (in Russian).

4. Кадушкина В.П., Грабовец А.И., Коваленко С.А. Результаты использования химического мутагенеза при селекции яровой твердой пшеницы // Достижения науки и техники АПК. 2016. № 2. С. 82-84.

Kadushkina V.P., Grabovets A.I., Kovalenko S.A. Results of Chemical Mutagenesis in Breeding of Spring Durum Wheat // Dostizheniya nauki i tekhniki APK. 2016. № 2. P. 82 84 (in Russian).

5. Мальчиков П.Н., Мясникова М.Г. Возможности создания сортов яровой твердой пшеницы (Triticum durum Desf.) с широкой изменчивостью параметров вегетационного периода // Вавиловский журнал генетики и селекции. 2015. T. 19. № 2. C. 176-184.

Malchikov P.N., Myasnikova M.G. Approaches to the development of durum wheat cultivars (Triticum durum Desf.) with wide variability of the growing season // Vavilovskiy zhurnal genetiki i selektsii. 2015. V. 19. № 2. P. 176-184 (in Russian).

6. Никитина Е.Д., Хлебова Л.П., Ерещенко О.В. Разработка отдельных элементов технологии клеточной селекции яровой пшеницы на устойчивость к абиотическим стрессам // Известия Алтайского государственного университета 2014. T. 2. № 3. C. 50-54. DOI: 10.14258/izvasu(2014)3.2-09.

Nikitina E.D., Khlebova L.P., Ereschenko O.V. The Development of Some Technology Elements of the Spring Whea Cell Selection for Resistance to Abiotic Stresses // Izvestiya
Altayskogo gosudarstvennogo universiteta. 2014. T. 2. № 3. P. 50-54 (in Russian)

7. Васильчук Н.С. Результаты селекции яровой твёрдой пшеницы на адаптивность // Вестник ОрёлГАУ 2006. № 2-3. C. 24-27.

Vasilchuk N.S. The results of breeding spring durum wheat for adaptability // Vestnik OrolGAU 2006. № 2-3. P. 24 27 (in Russian).

8. Гапонов С.Н., Попова В.М., Шутарева Г.И., Еременко Л.В., Цетва Н.М., Паршикова Т.М. Основные достижения и направления селекции яровой твердой пшеницы в ФГБНУ «НИИСХ Юго-Востока» // Зерновое хозяйство России. 2017. № 4. C. 17-21.

Gaponov S.N., Popova V.M., Shutareva G.I., Eremenko L.V., Tsetva N.M., Parshikova T.M. The main achievements and trends of spring durum wheat breeding in FSBSI 'RIA of South-East' // Zernovoye khozyaystvo Rossii. 2017. № 4. P. 1721 (in Russian).

9. Горянин О.И., Щербинина Е.В. Прямой посев яровой твердой пшеницы в Среднем Заволжье // Успехи современного естествознания. 2018. № 10. C. 45-49. DOI: 10.17513/ use. 36880 .

Goryanin O.I., Shcherbinina E.V. Direct seeding of spring durum wheat in the Middle Volga // Advances in current natural sciences. 2018. № 10. P. 45-49 (in Russian).

10. Методика государственного сортоиспытания сельскохозяйственных культур. М.: Колос, 1971. 239 с.

Methodology of state variety testing of crops. M.: Kolos, 1971. 239 p. (in Russian). 